\title{
THE ROLE OF DEVELOPMENT BANKS IN THE PROCESS OF ECONOMIC DEVELOPMENT- TWO LATIN AMERICAN EXPERIENCES: MEXICO AND BRAZIL
}

\author{
Victor Manuel Isidro Luna
}

Victor Manuel Isidro Luna, $\mathrm{PhD}$, University of Utah, is currently instructor at the National Autonomous University of Mexico, UNAM. Email: Victor.isidro@utah.edu

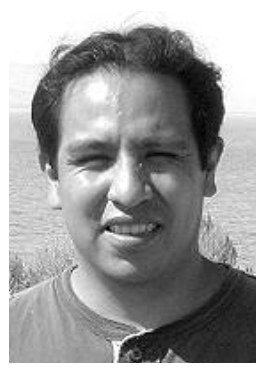

\begin{abstract}
This article aims to show the role of financing in economic development in two countries, Brazil and Mexico, after World War II (WWII) to present day. We do a careful historical review to see what sort of policies and what kind of structure two national development banks (Nacional Financiera [NAFINSA] from Mexico and Banco Nacional de Desenvolvimento Econômico e Social [BNDES] from Brazil) carry out in order to spark industrialization. Our research shows that these banks were successful at promoting growth (but not human development) in particular periods in their country's history (import substitution) and not successful in other periods (neoliberalism).
\end{abstract}

Key words: financing; Nacional Financiera; Banco Nacional de Desenvolvimento Econômico e Social; growth and development

\section{Introduction}

Historically, Latin American countries, since formal independence, have lacked the resources to finance economic development. They have tried to import such resources from abroad via foreign direct investment (FDI) or foreign loans. However, FDI came in small quantities, and loans provoked heavy burdens in debt payments that led to disastrous crises. 
From 2003 to 2007, several Latin American countries had current account surpluses and a notable increase in foreign-exchange reserves, which gave rise to the idea of the Banco del Sur (Bank of the South). This bank has the potential to (1) finance infrastructure (for instance, a gas or oil pipeline or railroads), (2) develop financial markets issuing debt (Bono del Sur), (3) provide a place for pooling surpluses or foreign-exchange reserves of Latin American countries (Monetary Fund of the South), and (4) eventually establish a new currency in the south (peso del sur, sucre, etc.). Following a meeting in Quito, Ecuador, in May 2007, at which it was announced that the Banco del Sur would be created on September 26, 2009, the presidents of Brazil, Argentina, Venezuela, Ecuador, Bolivia, Uruguay, and Paraguay signed an agreement establishing the bank with initial capital of US $\$ 20$ billion. The bank was intended to replace the International Monetary Fund (IMF) and the World Bank as a source of borrowed capital for countries in Latin America, in particular for infrastructure and social projects. Then, of the four possibilities for the Banco del Sur mentioned above, only number one-financing infrastructure - was chosen. This situation immediately suggests a historically important question for Latin America and the motivation for this article: what is necessary for this bank to succeed in its mission? What sort of structure and what sort of policies would be best suited for the development of such a bank, in the context of Latin America?

Brazil and Mexico are the two largest economies in Latin America. Both countries have had a development bank that was extremely successful during particular periods in their country's history and not so successful in other periods. These experiences, then, provide us with two natural experiments, two case studies, of development banks in Latin America. The economic question that will be addressed by this article is, what conclusions can be supported by a detailed study of these two development banks?

This article is divided into five sections, including this "Introduction." In Section 2, we define what a development bank is; Section 3 constitutes the core of this article, where we analyze the experience of a Mexican development bank, Nacional Financiera (NAFINSA), and describe the performance of a Brazilian development bank, Banco Nacional de Desenvolvimento Econômico e Social (BNDES); in Section 4, we study the similarities and differences between Mexico and Brazil with respect to the political economy of development banks, and in Section 5, we present concluding remarks.

\section{Defining a Development Bank}

Material reproduction of a society implies to achieve economic growth. For growing, a certain amount of capital is needed to ignite or to continue a production 
process. It has been suggested by Itoh and Lapavistas (1999) that Marx pointed out two kinds of capital which can bear interest. However, there is not an extended analysis of how growth has been financed in underdeveloped countries. The typical way some poor countries have tried to foster development in the 20th century has been through development banks. This section discusses four issues concerning development banks: first, what a development bank is; second, what sectors development banks can foster; third, what type of ownership can be possible; and finally, what kinds of enterprises, public or private, can receive resources. Our intention is to show how the present day development banks work.

A first step in constructing a definition of a development bank is to look for commonalities in the structures of institutions that are called development banks. Unfortunately, as Kane $(1975,13)$ points out, "There is no universal model to which development banks conform." Hence, structural commonalities cannot serve as a basis for a definition of development banks. Following several authors (Diamond 1957; Kane 1975; Bruck 1998; Armendáriz 1999; Lazzarini et al. 2002; De Luna-Martínez and Vicente 2012), we turn to the functions of the institutions as the basis for defining development banks. Once it is established that the definition of a development bank should come from its functions, the name "development bank" immediately suggests the two functions that an institution must fulfill to carry this label (both equally important): (1) it is a financial intermediary and (2) it must have the goal of promoting development (Maung 1973; Diamond 1981; Ramirez 1987; Bruck 1998). Both functions must correspond to the overall national economic policies carried out by the respective country.

Additional consideration of these two functions will help to further clarify what a development bank is. First, whereas it is a financial intermediary, it is not what is usually simply called a bank, a commercial bank, because the main activity of commercial banks is short-term lending. Development banks, in contrast, carry out some mixture of three activities: (1) long-term loans (similar to an investment bank, to be discussed below), (2) holding equities and ". . . managing specific companies as well . . providing financial support" (Diamond 1957, 5), and (3) providing technical assistance to companies.

Second, in relation to its objective of development, a particular development bank generally focuses on a limited number of specific sectors of the economy according to the needs of the country, such as agriculture, industry, or building infrastructure such as railroads, subways, universities, and hospitals.

There is disagreement in the literature about what sorts of sectors development banks should promote. Boskey (1959) argues that industrial activities should be the priority for a development bank. On the other hand, most authors have come to see development banks as appropriate for any sector of the economy for which the government wants to promote development. In particular, agricultural 
development banks flourished in the half century after World War II (WWII) until the neoliberal paradigm put a damper on all development banks.

There is also disagreement in the literature about the issue of public vs. private ownership of a development bank. No one argues that development banks should all be private, for to do so would be entirely at odds with the actual history of development banks since WWII. One group including Diamond (1957), Ramírez (1986), and De Luna-Martínez and Vicente (2012) argues that a development bank can be public, private, or a combination of both. A much smaller group argues that development banks should be "government-sponsored financial institutions" (Armendáriz 1999, 1; see also Bruck 1998).

Finally, there is also disagreement in the literature about what types of sectors should be promoted in terms of the ownership of the promoted industries. Diamond (1957) argues that a development bank should promote only the private sector of an economy. ${ }^{1}$ The opposite view is argued in a United Nation's (UN) document $(2005,35):$ “. . . Development banks are a financial instrument of national development policy whose performance is measured more in terms of social benefits generated." In our view, Diamond provides a terse definition of a development bank:

The principal function of a development bank is the provision of medium- and long-term finance for fixed assets. It also helps to provide, in addition to finance, such other essentials of productive investment as entrepreneurship, technical skills and managerial experience. It relies on the success of the enterprises it finances for recovery of the investment rather than on the security of collateral, and it does so in a manner that balances commercial standards of operation with economic benefit. (Diamond 1957, 4)

This background is all related to how development banks must function. However, banks have existed for many hundreds of years. Only in the 1800s, however, did some banks begin to focus on financing the development of production, and in particular industrial production. This focus, of course, was in part a result of the exponential growth of industrial production in the 1800s. This type of banking became known as "Investment Banking." By the nature of industrial production, this 19th-century investment banking involved the provision of medium- and long-term finance for fixed assets. Since financing is a central part of the operational definition presented above for development banking, this poses the question of how development banking differs from investment banking, which still exists today.

In brief, development banks are public institutions, ${ }^{2}$ whereas investment banks are private institutions, which means that a development bank's goal involves balancing commercial standards of operation with economic benefit (meaning 
economic benefit to the whole country). As Diamond (1957) and Gerschenkron (1962) argue at slightly greater length, development banks evolved because there was a widespread perception that the conventional financial institutions-the commercial banks - could not be relied upon to cope with economic backwardness and to promote rapid growth, for they were constrained by the short-term nature of their resources and by the short time-horizon against which they typically judged their investments. Thus, in the concept of the development bank are combined several strands of 19th- and 20th- century tradition: vigorous mobilization of financial resources and promotion of investment, special assistance to particular groups or regions in the country, the pursuit of broad national economic objectives by filling perceived gaps, or inadequacies in the elements required for productive investment.

In today's neoliberal dominated world, the later view of the inherent superiority of private economic institutions for almost all economic functions has come to dominate the thinking of most countries' political elite and policy-makers. The existing development banks were not dismantled. This article will see, however, the large changes in functions and underlying concepts that did develop under neoliberalism in the two development banks studied.

\section{Mexico and Brazil Experiences in Development Banking (NAFINSA and BNDES)}

Up to this point, we have provided a background of development banks in general. However, as we suggested in the previous section, a development bank obeyed each country's needs, which was the way a development bank obtained its specificity. Historically, the process of industrialization in England did not require a strong relationship between banks and industry. Other nations, such as Belgium, France, Germany, and Japan required a strong relationship (Cameron 1961, 1972a, 1972b). In some cases, this association was carried out through private banks, but in other cases, this relationship had to be fostered by the state because the private banks had neither the resources nor the willingness to do it (following the Gerschenkron hypothesis). ${ }^{3}$

\subsection{Mexico: The Experience of NAFINSA (1934-2010)}

The state's intervention in Mexican industrialization throughout the 20th century can be plainly seen because the need for providing long-term capital could not be satisfied by private capital for two reasons:

1. From 1864 to 1910 , financing was dominated by foreign banks.

2. From 1910 to 1920, Mexico's financial system was destroyed by the turmoil of the Mexican Revolution. 
Given these conditions, the Mexican government tried to foment growth after the Mexican Revolution. Two periods must be distinguished: (1) from 1925 through 1940, growth was sought by promoting agricultural activities and (2) from 1941 until the present day, growth has been sought by encouraging industrial activities either by import substitution (ISI) or by an export-oriented economy (OI). We now provide a brief summary of the first period, but it has to be kept in mind that our objective is to describe the second. The first period was characterized by the following government actions:

1. Pacifying the country after the armed revolution and the Cristero war (1926-29), which provided stability to the Mexican economy and the opportunity to plan long-term projects. Some scholars view this action as the beginning of the construction of the nation-state (see Fitzgerald 1978).

2. Creating new institutions and enacting new reforms. Among the institutions, the National Banking Commission and the Bank of Mexico, founded in 1924 and 1925, respectively, were tasked with the centralization of the issuing of money. By means of centralization, the state could then manage national currency, exchange rates, and interest rates. Considering the reforms, the Banking Reform of 1931 was thought to have restored the liquidity of the banks. These events were important not only because money was controlled entirely by foreign banks but also because the newly established institutions permitted abandoning the gold standard in 1931.

3. Founding some specific key institutions, for example, the Agriculture Bank Credit in 1926 under the presidency of Plutarco Elias Calles (1924-28).

The second period started roughly in 1941 and continues today. However, two subperiods can be identified: 1941 to 1981 and 1982 to the present. The first subperiod is called in the literature the import-substitution (ISI) model and the second, the neoliberal period.

The relevant issues for sparking industrialization in the first subperiod were as follows: (1) the idea of encouraging the economy through the state with a capitalism program with the objective of shaping private Mexican companies, (2) the USA and England's need for manufactured goods during WWII, and (3) the access of Mexico to international capital markets after solving the debt controversy with the USA about the expropriation of oil.

Having this background of Mexican economic conditions before and during the 1930s, we now turn to how a development bank, NAFINSA, emerged and functioned in the ISI and the neoliberal period.

\subsubsection{The Foundation of NAFINSA (1934-40)}

NAFINSA was founded in April 1934 by President Abelardo L. Rodríguez with equal participation of public and private capital, although most disbursements 
were made by the state. In that period, the rate of economic growth in Mexico was $4.7 \%$, boosted primarily by the agricultural sector. NAFINSA had the following functions: (1) to develop capital markets by issuing its own securities since 1937, (2) to be a legal agent of the government to its domestic and foreign creditors, and (3) to be an investment promoter. Yet, NAFINSA's main function was to provide liquidity to the monetary system in order to foster the agricultural sector by means of selling real estate that had been frozen in the accounts of the Mexican private banks from the years of the Revolution until 1934. Besides, because of the existence of an agricultural credit bank and the fact that President Lázaro Cárdernas had compromised with the agricultural sector, the role played by NAFINSA in the country's development during these years was marginal, and even NAFINSA had to cede its resources to the Agricultural Credit Bank (Ares 2007). However, during that period, NAFINSA reorganized the banking system in Mexico, fostered the capital market (Blair 1964), and carried out other activities such as the construction of one hospital and participation in sectors such as steel, beer, electricity, and paper (Ares 2007).

\subsubsection{NAFINSA as an Industrial Promoter (1941-47)}

For Mexico, this period was characterized by economic growth and inflation. The growth rate was $5.6 \%$ and started a structural change in the Mexican economy via industrialization. The nascent NAFINSA's functions were established under a new law in 1940 (Aubey 1966), which emphasized the role of the bank in developing the stock market, being a legal agent of the government to its domestic and foreign creditors, and promoting industrialization. As a participant in developing the stock market, the bank issued its own securities, such as Certificados de Participacion and Titulos Financieros; the latter were denominated in dollars. As a legal agent of the government, NAFINSA negotiated the first loans granted by the US Eximbank. However, its main function was to foster industries in which the private sector was unwilling to intervene. A proof of this function is the 56-fold increase in NAFINSA investments in securities from 1940 to 1946. Additionally, NAFINSA developed several companies, including Altos Hornos de Mexico (steel), Nueva Compania Eléctrica of Chapala (electricity), Carbonifera Unidad de Palau (coal), Cementos Guadalajara (cement), Union Forestal de Jalisco and Calimo (wood), Compania Industrial Atenquique (paper), Empacadores de calidad (packing), and Guanos and Fertilizantes (fertilizers).

Table 1 depicts NAFINSA's importance. It summarizes four elements: (1) the percentage of NAFINSA's credit out of its total financing, (2) the percentage of NAFINSA's securities out of its total financing, (3) the percentage of NAFINSA's financing with respect to total financing in Mexico, and (4) NAFINSA's financing 
as percentage of gross domestic product (GDP). The 6-year period represented in Table 1 shows that NAFINSA granted resources mainly via security investments and that the role of credit became important only in 1946 and 1947. In addition, NAFINSA's financing increased from $0.52 \%$ of GDP in 1942 to $2.37 \%$ of GDP in 1947 (see also Figure 1).

Table 1 NAFINSA Distribution of Total Financing and Total NAFINSA as Percentage of GDP and the Banking System

\begin{tabular}{lccccccc}
\hline Year & 1941 & 1942 & 1943 & 1944 & 1945 & 1946 & 1947 \\
\hline Credit & 16.43 & 8 & 4.2 & 8.8 & 22.7 & 31.4 & 32.2 \\
Securities & 70.08 & 86.4 & 89.6 & 82.2 & 67.7 & 56.3 & 45.7 \\
Total financing over total & 3.15 & 4.8 & 12.3 & 15 & 24 & 23.9 & 26.7 \\
financing of the banking system & & & & & & & \\
NAFINSA's financing/GDP & 0.52 & 0.23 & 0.75 & 0.93 & 1.79 & 1.74 & 2.37 \\
\hline
\end{tabular}

Notes: GDP: gross domestic product; NAFINSA: Nacional Financiera.

Source: Adapted from Villa (1976).

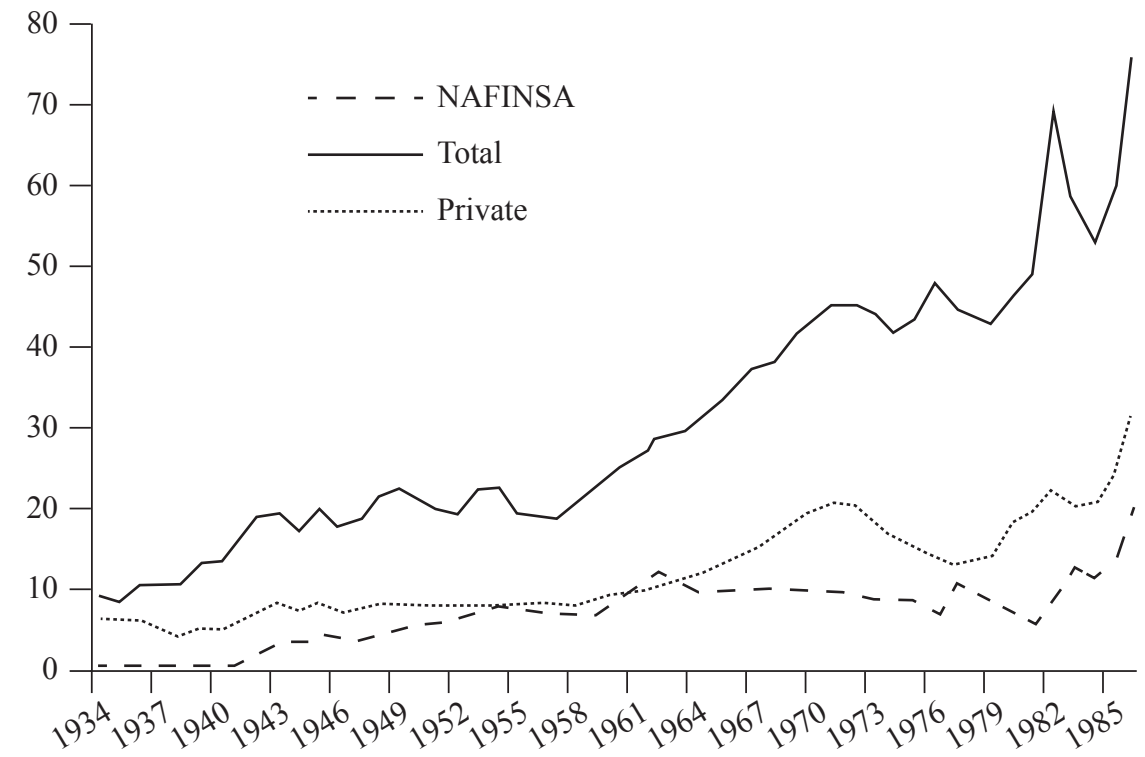

Figure 1 Total Financing in Mexico from 1934 to 1984. Percent of GDP

Notes: GDP: gross domestic product; NAFINSA: Nacional Financiera.

Source: Author's elaboration of data from NAFINSA, Informe Anual, Mexico, over several years. 


\subsubsection{NAFINSA during the Period of Stable Development (1948-70)}

This period had a high rate of economic growth in Mexico as a result of the outstanding performance of the world economy after WWII with the expansion of production and international trade led by the USA. This process of growth was distributed unevenly in different countries. Western Europe and Japan benefited the most, but underdeveloped countries also benefited from these decades of growth because of an abundant demand for raw materials and the transfer of capital via FDI.

The economy of Mexico grew at a rate of $6.1 \%$ for almost the entire period, GDP per capita almost doubled, and there was low inflation as well as stability in the exchange rate (this growth was called the Mexican miracle or the stable development). The situation with the Mexican sector of production was positive for two reasons: (1) the arrival of FDI, which contributed to the shaping of the Mexican capitalist sector during the period of the ISI, and (2) the increase in exports of primary products, mainly maize (due to the Green revolution). In this period, the role assigned to NAFINSA changed with respect to the previous period (1941-47) because industrial growth showed that Mexico lacked (1) an adequate infrastructure such as in transports (railroads) and communications, (2) an important complex of basic industries, and (3) an efficient system of agricultural irrigation. Scholars such as Ares (2007) point out that NAFINSA's role changed because the industrial capitalist sector had become hostile to NAFINSA as a result of the sector's perception that NAFINSA's participation in Mexican industrialization was too big, resulting in crowding out effects. However, it was common for development banks at that time to be a complement to the private sector in building infrastructure (see Amsden 2001; Guth 2006).

The Organic Law of December of 1947 established that NAFINSA had a role to play in supporting the private sector but without much participation in directing the industrialization of Mexico. Given that, almost all the resources of NAFINSA were used to finance infrastructure using credit. NAFINSA slowed down its entrepreneurial role and its purchases of securities. Table 2 illustrates how infrastructure turned out to be the main objective of NAFINSA, again mainly in the 1960s. By 1968, infrastructure represented $72.1 \%$ in NAFINSA's credit granted.

Consequently, NAFINSA had a large role in granting credit to Mexican industries. A proof of this can be appreciated in Figure 1. It is important to note that NAFINSA's participation in total financing peaked in the 1960s and diminished slowly through the 1970s. These upturns and downturns came as no surprise, since NAFINSA should have only complemented the private sector.

However, the entrepreneurial role of NAFINSA was not at all unimportant during this earlier period (1948-70). NAFINSA had a few companies, but due to their total production, they were among the largest in Mexico. These companies 
Table 2 Division of Total NAFINSA Financing

\begin{tabular}{lccccccc}
\hline & 1947 & 1953 & 1958 & 1963 & 1964 & 1968 & 1970 \\
\hline Infrastructure & 28.5 & 47.23 & 48.6 & 61.4 & 64.9 & 72.1 & 70.9 \\
Industry & 71.5 & 27.26 & 39.86 & 30 & 25.6 & 23.8 & 29 \\
Basic & 27.4 & 12.35 & 13.99 & 10 & 7.3 & 7.5 & 7.4 \\
Other industries & 44.1 & 14.91 & 25.87 & 15.7 & 18.3 & 16.3 & 21.6 \\
Other activities & - & 25.51 & 11.5 & 8.6 & 9.5 & 1.6 & 0.1 \\
\hline
\end{tabular}

Note: NAFINSA: Nacional Financiera.

Source: Adapted from López (2009).

were involved mainly with basic industries. NAFINSA could finance large companies because of its good financial situation, obtaining resources from the government and from abroad via two sources: (1) issuing securities and (2) bringing in loans from the Word Bank and the Inter American Development Bank. Some of the companies that NAFINSA fueled in this period were Diesel Nacional, S.A. (automobiles), Metalúrgica Peñoles, S.A. (mining), Constructora Nacional de Carros de Ferrocarril (railroads), and Fertilizantes Monclova (fertilizers). In addition, NAFINSA helped in the "Mexicanization" of several enterprises such as in mining, electricity, food, tobacco, and aluminum.

Notwithstanding NAFINSA's entrepreneurial role, the presence of many foreign companies (the majority from the USA) in the most dynamic sector of the Mexican economy had pernicious consequences. These companies operated with backward technologies in international terms, but by operating in oligopolistic markets and under protective system of public subsidies, they could achieve higher profits than the average in the Mexican economy (Garrido 2002). In addition, the foreign companies consistently remitted large profits to their home countries.

A further pernicious effect on the Mexican economy was its way of financing growth. In the Mexican structure of production, there was a very strong link between industry and banks (insider lending). The relationship was expressed in two ways: companies that owned banks and banks that owned companies. There was a discussion among scholars about which of these relationships were more important. Fitzgerald (1978) thought that both groups were powerful. However, Garrido (2002) asserted that there was less competence in the Mexican banking sector, and therefore banks dominated the accumulation of capital. For this structure, the large profits that were obtained by both industrial and financial groups were moved outside the country or kept in the financial system.

\subsubsection{NAFINSA in Times of Crisis (1971-81)}

This period was troublesome and turbulent for both the world economy and Mexico. At the international level, this period encompassed the world crisis in 1973/74 and 
the beginnings of the Latin American debt crisis. The latter provoked a structural change in the Mexican economy that was characterized by a slow growth rate and the adoption of a neoliberal model. During this period, the growth rate was quite unstable and severely plummeted in 1977 . The growth rate immediately recovered because of the discovery of vast oil deposits. Economic problems in the Mexican economy during the 1970s were attributed to the following: (1) the end of the ISI, which had been dominated by foreign companies; (2) the weakening of the agricultural sector that had as a consequence the decrease in foreign-exchange reserves that had been important to foster the expansion of the industrial sector; (3) the importation of food supplies; (4) the deterioration of the trade balance, which resulted in the necessity of foreign borrowing during the 1970s; and (5) the blatant inequality of income distribution; even though income per capita had doubled during the period of stable development, wages were controlled and income distribution worsened (Valle and Martínez 2011).

As Ares $(2007,219)$ has pointed out, the economic problems of this period were exacerbated by political considerations such as the outbreak of social movements in rural areas of Mexico, the impact of the riots in 1968, and the discontent of the middle classes, which finally caused the Mexican government to spend more on social programs in order to gain legitimacy. Mexico could not finance its development and needed capital from abroad. Borrowing increased significantly due to the world economic crisis, as developed countries and their commercial banks had available a very large mass of resources but did not want to invest in their own countries (Green 1998). There was a massive accumulation of resources in the financial system as Eurodollars, and underdeveloped countries were candidate locations for these surpluses. This situation was highly appreciated in Mexico, where external debt folded by 12 from 1970 to 1982. While Mexico had growth rates higher than international interest rates, debt was not a problem-even the discovery of vast deposits of oil contributed to finance infrastructure and obtain more debt. However, when the United States increased their interest rate in 1979, Mexico could not pay the debt service (interest and amortization), which was the origin of the debt crisis.

Developments banks and NAFINSA experienced the same turbulence. Financing granted for commercial banks fell from $20 \%$ in 1970 to $18 \%$ of GDP in 1980. Consequently, development banks had to cover that gap. As the Mexican state increased its participation in the gross fixed capital formation (GFCF) from 33\% in 1970 to $43 \%$ in 1980 , development banks had to increase their total financing. Therefore, it can be claimed that development banks were spending too much through the 1970s in order to promote investment, but in the same vein, it can be argued that the private sector was encouraging minimal industrial activities (Table 3). 
Table 3 Composition of NAFINSA's Total Financing

\begin{tabular}{lccccc}
\hline Sector & 1963 & 1974 & 1979 & 1981 & 1983 \\
\hline Infrastructure & 60.3 & 65.1 & 55.7 & 45.6 & 20.5 \\
Industry & 35.6 & 30.6 & 28.4 & 32.4 & 54 \\
Basic & 18.4 & 10.3 & 16.7 & 23.1 & 41.4 \\
Manufacturing & 17.2 & 20.3 & 1.7 & 9.3 & 12.6 \\
Other & 4.1 & 7.9 & 15.9 & 22 & 25.5 \\
Total & 100 & 100 & 100 & 100 & 100 \\
\hline
\end{tabular}

Note: NAFINSA: Nacional Financiera.

Source: Adapted from Ares (2007).

The national turbulence of 1971-81 affected NAFINSA, the largest of the development banks, because

1. NAFINSA had to operate with scarce resources, and almost all the inflow of money came from abroad, mainly via private banks instead of international agencies such as the World Bank or the Inter American Bank of Development;

2. NAFINSA, unable to obtain domestic deposits, received almost all its resources in dollars;

3. NAFINSA could not get domestic deposits because it had only one branch in Mexico in 1971, and the approval for more branches was carried out slowly. As a result, NAFINSA could not satisfactorily compete with private commercial banks;

4. NAFINSA performed projects with a similar objective, surpassing the needs of the Mexican economy in some products. For example, it financed Altos Hornos de Mexico and Las Truchas, both of which were involved in the production of steel; and

5. NAFINSA had to lend to the public sector at very low interest rates, as, for example, to the Bank of Mexico.

However, during this period, NAFINSA's commitment to financing industrial activities grew in comparison with its financing of infrastructure. The entrepreneurial role of NAFINSA increased starting in 1976 with the creation of 18 new companies. Some of the companies that NAFINSA fostered or contributed to their Mexicanization were Cananea (copper), El Fuerte (foods), Azufrera (sulfur), Autlan (copper), Las Truchas (steel), Altos Hornos (steel), and other companies involved with the production of paper, textiles, and electricity.

\subsubsection{Financial and Commercial Liberalization (1982-Present Day)}

In this last period, the main characteristics of Mexico and NAFINSA are as follows: 
1. After the debt crisis, Mexico adopted a stabilization program (depreciation and inflation control) and a structural change that was summarized under the 10 policies of the Washington consensus.

2. Trade liberalization for large companies went well because soon after the North American Free Trade Agreement Mexico became one of the greatest exporters in the world (more than $30 \%$ of GDP are exports), mainly in auto parts. Unfortunately, Mexico's greater import needs resulted in a negative trade balance from the 1990s onward.

3. Living conditions of Mexicans worsened from 1970s onward; the real minimum wage could buy one and a half fewer products than it could buy in the 1970s. These conditions represented the most severe deterioration in Latin America so far (Valle and Martínez 2011).

4. Mexico had to fulfill a heavy burden in debt service payments, being obligated to pay amortization and interest greater than the loans the country had received from 1970s onward.

5. The financial liberalization that had as an objective the increase in the rate of saving only provoked a return to the past for Mexico. This situation should be mentioned because of the high concentration of deposits and assets in the banking system. In 2003 , three foreign banks controlled more than $60 \%$ of the total assets in Mexican banks, and the totality of foreign banks also controlled almost $80 \%$ of the total assets after the wave of privatization from 1991 to 1992 (see Garrido and Martínez 2004; Guerrero, López-Calva, and Walton 2009). This concentration is even worse than in the past, because in 1950 there were 240 banks in Mexico; four of them controlled $40 \%$ of the total assets (see Garrido 2002).

Liberalization and deregulation had negative effects on NAFIN. ${ }^{4}$ Notwithstanding the increase NAFIN had on its financing right after the debt crisis, above all, in industrial activities, the purpose of this increase was to make state-owned companies ready to be sold. Among other effects, in 1986, NAFIN mostly supported the production of exportable goods and did not own more than $20 \%$ of the stocks in its companies. Additionally, the companies that had to be encouraged were small and medium enterprises (SMEs).

In 1989, NAFIN was associated mainly with a second-tier financial institution, which assigned credit primarily via private banks. The aforementioned policies had two goals: (1) the Mexican authorities at the beginning of the 1990s thought that operating development banks in the 1970s had been costly, and (2) the public sector had to obtain resources via private mechanisms and not through development banks such as NAFIN. Development banks were dedicated to very focused aspects of financing and were no longer promoters of industrialization. 
They had to bear heavier restrictions than the commercial banks, as, for example, the quantity of reserves they had to hold was $10 \%$, whereas commercial banks had a ceiling of $8 \%$.

Furthermore, NAFIN engaged in privatization between the end of the 1980s and the beginning of the 1990s that consisted in selling out the majority of NAFIN's companies. In 1981, NAFIN had 88 companies; by 1994, it had only 32 (Ares 2007). NAFIN's financing as a percentage of GDP decreased and was too low when compared with the levels that prevailed in the 1950s or with the anticyclical role that the government should have in a time of crisis (see Table 4).

Table 4 NAFIN's Financing and Private Credit as a Percentage of GDP

\begin{tabular}{lcc}
\hline Year & NAFIN's over GDP & Commercial credit over GDP \\
\hline 1998 & 4.2 & 19 \\
1999 & 3.42 & 16.92 \\
2000 & 3 & 14.23 \\
2001 & 3.18 & 12.96 \\
2002 & 3.7 & 13.13 \\
2003 & 3.19 & 11.92 \\
2004 & 2.19 & 10.96 \\
2005 & 1.87 & 11.8 \\
2006 & 1.37 & 12.73 \\
2007 & 0.85 & 14.38 \\
2008 & 1.11 & 15.6 \\
2009 & 1.99 & 15.84 \\
\hline
\end{tabular}

Notes: GDP: gross domestic product; NAFINSA: Nacional Financiera.

Source: Data from NAFINSA, Informe Anual, Mexico, several years.

The description of this last period concludes the section dedicated to NAFINSA. In summary, it is important to distinguish the following ideas: (1) Mexico tried to build some institutions such as the Central bank in 1925 and development banks such as NAFINSA in 1934 in order to promote economic development; (2) these institutions were important because one part of the Mexican financial system was destroyed by the Revolution and another part was dominated by foreign interests; and (3) NAFINSA encouraged the Mexican economy during the period of stable development and contributed to the shaping of the national capitalist sector.

However, with the crisis of the 1980s, NAFINSA faced a structural adjustment that caused its functions to involve the promotion of SMEs and made NAFINSA a second-tier bank. The financial and commercial liberalization did not provide more credit to Mexican companies, and the only result of liberalization was the foreignization of both banks and industries and slow growth rates. 


\subsection{Brazil: BNDES 1952-2010}

Now, we proceed with an analysis of how Brazil tried to spark economic growth after WWII; we describe BNDES' situation from 1952 to the present. Three subsections are used to accomplish this task: (1) the "Similarities and Differences Between the Economic Histories of Mexico and Brazil in the 20th century" section, (2) the "BNDES from 1952 to 1982" section, and (3) the "BNDES from 1983 to the present day" section.

\subsubsection{Similarities and Differences between the Economic Histories of Mexico and}

Brazil in the 20th century

Showing how Brazil financed development throughout the 20th century is the main purpose of this section. First, we present a brief background of the Brazilian economy followed by a summary of the similarities and differences between the economic history of Brazil and that of Mexico. This, later on, will allow us to shed light on how Brazil, specifically, uses finance to foster development.

The economic histories of Mexico and Brazil had similarities and differences during the 20th century. The similarities include the following:

1. The colonial heritage that led to an export-oriented agricultural economy. In the case of Brazil, the main product was coffee.

2. Blatant social, economic, and political inequality that was not reduced even in the presence of high and sustained economic growth as during the period from 1940 to 1980 (Aguilar Gutiérrez 1995; Gonzaga and Machado 2003). This inequality was worse in Brazil than in Mexico because Brazil did not have any land reform in the 1930s.

3. A lack of capital and recurrent problems with external debt, defaulting in the 1930s due to the loss of foreign-exchange reserves caused by the Great Depression and the downturn in terms of trade.

4. A very slow growth rate from 1900 to 1940 , a high and sustained growth rate from mid-WWII until the 1970s, and a slow growth rate from 1982 onward.

An additional characteristic, especially before the creation of BNDES, was a period of economic and political stability in the 1950s and 1960s that existed in spite of Getulio Vargas' suicide (1954) and the military coup in 1964 and that permitted the construction of the Brazilian national state and the opportunity to carry out long-term projects (Castro 2009).

However, several differences between Mexico and Brazil and their economic histories are specifically related to money: 
1. Brazil had stronger private banks than Mexico and granted short-term loans in the early 20th century. Brazil attempted, unsuccessfully, to promote long-term loans (Hermann 2010). ${ }^{5}$

2. The history of banking in Brazil is more ample than that of Mexico and very different. On one hand, Mexico started with development banks, the Banco del Avío Minero (1784) and the Banco del Avío (1830), with the clear goal of promoting industrialization. On the other hand, Brazil started with a public bank in 1808, the Bank of Brazil (Banco do Brasil), which was founded by the Portuguese crown through public offerings with the objective of avoiding the outflow of gold and financing wars.

3. The consolidation of government institutions to deal with money was instituted slowly and recently in Brazil. The Caixa de Mobilizaçao Bancária (CAMOB) in 1932 managed mortgages, and the Superintendencia da Moeda e do Credito (SUMOC) in 1945 managed exchange rates. This backwardness in money institutions was perhaps due to the strong agribusiness sector and to the Brazilian industrialization project, which only became more clear through the 1950s and 1960s (Cardoso 1968; Da Conceição Tavares 1977).

Under these conditions, Brazil established BNDE (Banco Nacional do Desenvolvimento Econômico) in November 1952, based on the Joint Brazil-US Mission (1950-1952) (Baer and Villela 1980). Unfortunately, BNDE started operations in September 1953. The bank was created in order to finance purchases of equipment and to solve bottlenecks (similar to NAFINSA's role during the 1950s) caused by the previous periods of industrialization. In this sense, the role of BNDE was much smaller than that of NAFINSA because both its resources and entrepreneurial functions were so limited.

\subsubsection{BNDES from 1952 to 1982}

The first years of operations for BNDE (1953-1956) were troublesome because the bank did not have sufficient resources from the Eximbank or from the World Bank and had few available public funds. Only priority projects were attended to and the BNDE's participation in the GFCF was only 3\% in 1956.

Following the idea of the National Development Plan (Plano do Metas) to increase the funds of BNDE during the government of Juscelino Kubitschek (1956-1961), the following measures were taken: “. . . a progressive additional income tax and a $4 \%$ tax were placed on undistributed profits. In addition, insurance and investment companies were still required to contribute $25 \%$ of their funds to BNDE project ..." (Baer and Villela 1980, 427), and finally, the Eximbank and the World Bank agreed to increase the number of loans to Brazil.

These measures permitted an increase in the quantity of resources available for BNDE, but again only priority projects were attended to because long-term credit 
was not easy to obtain (Studart 1995). Even though Brazil had started its industrialization process 20 years before the foundation of BNDE, investment projects were funded through either autofinancing or the Banco do Brazil. Therefore, when BNDE was founded, it was the resource for infrastructure and industry.

BNDE was founded almost entirely with public capital, and at that time, the state made a huge effort to support industrialization. Government spending surpassed receipts from 1953 until the mid-1960s, especially at the end of this period. This spending was dedicated in a high proportion to infrastructure (see Sochaczewski 2003). Several factors account for this situation. First, BNDE was dedicated to building infrastructure, such as communications and the steel and electricity industries. Second, Brazil financed new industries in consumer goods and SMEs. Almost all resources granted from the 1950s to the mid-1960s were to the public sector.

However, there was a change in financing development during the reform of 1964 to 1967. During this period, Brazil obtained resources from the stock market following the model of industrialization in the USA (Hermann 2002). This reform included letting the credit institutions issue liabilities with monetary corrections clauses, “. . . tax exemption for savers and tax reduction for open companies was introduced in $1966 \ldots$... [and the] Brazilian economy was opened up to direct foreign investment and loans ..." (Hermann 2002, 78). Right after its implementation, the reform produced good results, for the following reasons: (1) the number of financial institutions increased, (2) the quantity of bank loans grew as a percentage of GDP, (3) nonbanking institutions grew in number (see Hermann 2002), and (4) Brazil had its more important phase of growth in its entire history, called the "Brazilian miracle," from 1968 to 1973 (Araujo, Carpena, and Cunho 2008). In the end, that reform caused (1) a higher concentration in assets in the banking system, (2) investment banks supplied mainly working capital, (3) long-term deposits in private banks were not relevant in the process of development, and (4) capital markets did not provide any significant quantity of resources for economic development (see Hermann 2002; Stallings and Studart 2006). As a result, BNDE was the main contributor to the development of Brazil.

At the end of the 1960s, BNDE modified its way of obtaining resources. Resources were mainly acquired by collecting $1 \%$ of taxes, both over income or profits and through the allocation of resources from the federal budget. In numbers, the disbursements of BNDE represented 3.2\% of the GFCF during the period 1964-1967. The main industry supported was steel. Fewer resources were allocated to nonferrous metals, chemicals, petrochemicals, paper, machinery, and other industries.

In the 1970s, BNDE financed new industries in intermediate and capital goods, which constituted 5\% of GFCF during the period 1970-1973 and 8.9\% of GFCF 
during the period 1975-1979. BNDE, however, moved into financing private activities rather than public (Diniz 2004; Guth 2006). Therefore, BNDE largely contributed to the fast economic growth that Brazil experienced from the 1950s until the end of the 1970s because this was the period in which the government's participation in GFCF peaked (see Sochaczewski 2003).

These three decades, in spite of the presence of high volatility, were good for economic growth, with an annual growth rate above $6 \%$. Later, in the 1980 s, came the debt crisis, which was a very strong backward movement for the Brazilian economy. At this point, Mexico and Brazil shared and differed in several aspects in their economic histories. These aspects and the situation concerning BNDE from 1983 to the present day are described in the following subsection.

\subsubsection{BNDES from 1983 to the Present Day}

During this period, Mexico and Brazil shared the following characteristics: (1) dependency on foreign borrowing mainly through the decades of the 1970s, 1980s, and 1990s; (2) adoption of a stabilization program and a structural change under the guidance of the 10 policies of the Washington consensus; and (3) low rates of economic growth from 1982 onward. However, unlike Mexico, Brazil had high persistent inflation and was hit more severely by the oil shocks in the 1970s.

Although GDP declined severely in the 1980s, BNDE's functions were not damaged so much at the beginning of the period. As Golonbek and Urturi (2009, 16) pointed out, these functions in fact become more extensive.

In 1982, Decree Law No. 1940 establishes a significant change in its functions. The BNDE will be renamed National Bank of Economic and Social Development (BNDES). In this context, the BNDES acquires some new powers for the realization of programs and projects prepared by the Presidency of the Republic, particularly related to social issues such as food, affordable housing, health, education, justice, and small producers.

Unfortunately, Brazil did not have the resources to finance its economic development. Growth rates in the 1980s remained stagnant and debt service increased to almost 7\% of GDP at the beginning of the 1980s. Like Mexico, Brazil had to pay more in debt service than the loans it received from the 1970s onward.

In the 1980s, BNDES financed programs in energy, agriculture (supporting SMEs), and a few social projects and obtained resources from new funds such as the Navy and the workers' protection fund. Despite all that, BNDES' disbursements contracted $64 \%$ in real terms from 1979 to 1990 . Regarding disbursements as percentage of GFCF, they dropped from $10.6 \%$ to $3.3 \%$ in the same period. Spending on social projects remained marginal throughout the $1990 \mathrm{~s}$ (see Diniz 2004). 
From the end of the 1980s onward, Brazil tried to bring down inflation and gradually implemented financial and commercial liberalization. Universal banking, deregulation, and openness to foreign investors in the Brazilian market capitals were implemented in 1988. At the beginning of the 1990s, import tariffs were decreased. As a result, imports skyrocketed during the 1990s, which led to a negative trade balance. The trade balance became positive only at the beginning of the 2000s. In 1994, Brazil established a stabilization program called the Plano Real, which included the reconstruction of the banking system through privatization, where those who benefited the most were international and Brazilian industrial and financial groups. Additionally, the Plano Real implemented a high rate of interest in order to attract capital (one of the highest in the world). Along with the aforementioned events, Brady's Plan was renegotiated (as a result of which the burden of debt diminished at the beginning of the 1990s). Finally, in the 2000s, foreign banks had a huge penetration in the Brazilian banking system.

Although all these measures were taken to strengthen the Brazilian banking sector, credit remained stagnant. Stallings and Studart describe the situation as follows: "the government offers large amounts of well-remunerated bonds to finance its deficits. These attract the banks to buy securities rather than make loans, thus feeding capital market growth" (Stallings and Studart 2006, 230).

In the 1990s, BNDES financed both private infrastructure and export programs and participated intensively in the process of privatization. As percent of the GFCF, its disbursements were $3.1 \%$ in $1989,4.1 \%$ in $1990-1994$, and 8.7 from 1995 to 1998. The proportion of participation was high in the 1990s because of the process of privatization. BNDES had to buy companies, make them profitable, and then immediately sell out.

From the end of the 1990s until 2001, resources granted by BNDES were low. Disbursements provided by BNDES have only grown in the last 7 years, and mainly during the time of the current economic crisis. In that time, Brazil and BNDES boasted very important companies in key sectors such as in energy with Petrobras and in mining with Vale do Rio Doce. BNDES also fostered infrastructure and programs of exports and innovation. Some of the companies financed by BNDES were among the largest private companies in the world (see Table 5) (see Lazzarini et al. 2002). In spite of that, it has to be mentioned that inequality in Brazil has not shown any improvement from 1980 to 2009; the Gini coefficient was 0.59 in 1980 and 0.58 in 2009. In addition, the number of wealthy people in Brazil has skyrocketed in the last 3 years, and Brazil has large public and private banks, but they are not granting any credit to the Brazilian population.

For growing, a certain amount of capital is needed to ignite or to continue a production process. It has been suggested by Itoh and Lapavistas (1999) that Marx pointed out two kinds of capital which can bear interest. However, there is not an 
extended analysis of how growth has been financed in underdeveloped countries. The typical way some poor countries have tried to foster development in the 20th century has been through development banks.

Table 5 BNDES' Disbursements according to the Type of Financing

\begin{tabular}{lccc}
\hline Year & Private & Public & Total \\
\hline 2005 & 96.1 & 3.9 & 100 \\
2006 & 93.4 & 6.6 & 100 \\
2007 & 95.5 & 4.5 & 100 \\
2008 & 97.1 & 2.9 & 100 \\
2009 & 74.9 & 25.1 & 100 \\
2010 & 78 & 22 & 100 \\
2011 & 91.6 & 8.4 & 100 \\
\hline
\end{tabular}

Note: BNDES: Banco Nacional de Desenvolvimento Econômico e Social.

Source: BNDES (2012).

\section{Similarities and Differences between Mexico and Brazil with Respect to the Political Economy of Development Banks}

After reviewing development banking experiences in both Mexico and Brazil, we proceed to highlight some political and economic similarities and differences between the two countries with respect to the processes of financing development. Subsequently, we analyze some remarkable facts about the political economy of development banks.

Mexico and Brazil underwent the following: (1) foreign economic dependency; (2) blatant social, economic, and political inequality; (3) recurrent external debt defaults; and (4) a lack of capital to finance development. All these problems started in the 19th century with an export-oriented model of growth but without a concomitant solution to the problems. Another similarity is that both countries had a period of political stability during the 1950s and 1960s (the years of the ISI model). In Brazil, this stability occurred in spite of Getulio Vargas' suicide and the military coup in 1964. A final similarity is related to Brazil and Mexico's respective processes of industrialization, in which the ISI model was not as successful as desired, for four fundamental reasons. First, building the stock of capital goods so that they would not need to be imported for continued industrialization was a slow process. Second, the processes of industrialization were dominated by foreign enterprises and countries, above all the USA. Third, Brazil and Mexico carried out the ISI depending on the First World countries' level of economic activity. Finally, the two countries had hoped that ISI would result in greater economic 
independence. In fact, industrialization changed only the nature of the dependency relationship, while the commodity composition of imports changed, producing many industrial goods requiring large imports. The import coefficient did not decline significantly, and the result was that the two countries remained at least dependent on foreign trade and imports as its rate of economic activity.

However, Mexico and Brazil had several differences in their economic histories. Unlike Mexico, Brazil did not experience an armed conflict that destroyed its financial system and a great part of its economy, and it was not subject to such a contracting effect provoked by the Great Depression. These two facts were important because Brazil was able to retain the remnants of the exportoriented model (the old oligarchy), whereas in Mexico, the petite bourgeoisie had seized power and put in place an industrialization project. This is the reason the consolidation of governmental institutions to deal with money was instituted slowly and recently in Brazil.

These differences were not manifested in divergent growth patterns in the two countries. The growth rates of both countries after WWII and their twofold nature with ISI and the neoliberal periods were similar. First, from the second half of the 1930s until the end of the 1970s, Brazil and Mexico had annual rates of growth around $6 \%$. In both countries, there was a process of convergence with the USA. Second, after 1980, Mexico and Brazil instituted neoliberal policies, and the average growth rate has remained around $2 \%$ since then. The processes of convergence with the USA stopped. Why did different ways of financing development lead to the same results?

First, we have to establish that in both periods we have analyzed, ISI as well as supporters of neoliberalism were capitalists whose main objective was obtaining the largest possible profit in the short-run. As the petite bourgeoisies of Mexico and Brazil were weak, the state had to commit to finance development. The creation of companies and investments in infrastructure through development banks resulted in an increase in production and in the volume of employment. Many instruments of industrial policy were employed and the state possessed a high degree of discretionary power to influence many variables and prices in the economy. Capitalists of both countries did not dominate the structure of production of their respective nations, but they were resilient and their numbers increased during the ISI and in the subsequent neoliberal period.

However, if the petite bourgeoisies required the state during the ISI, they did not need a strong state to direct the economies during the neoliberal era. A broader and stronger domestic wealthy class exists in Latin America today than in the time of the greatest successes of NAFINSA and BNDES. As opposed to then when the weaker wealthy class often saw the extensive intervention of the state into the economy and in particular into the process of development as a tool to promote 
interests, today's wealthy class generally adheres to the dominant neoliberal view among capitalists that a capitalist market economy with minimal direct government is better for their class interests.

Of course, 30 years of neoliberalism worldwide has caused a significant demobilization of the working class in its defense of its rights. To be sure, Latin America is the leading partial exception to this, particularly in the new processes in Venezuela, Bolivia, and Ecuador, but more broadly in the masses throughout Latin America. Nevertheless, there too there has been an important weakening of the institutions through which the popular classes could exercise pressure from below in favor of progressive liberal policies such as state development banks with social as well as narrow economic missions. It is unclear at this moment in history-with the world capitalist system suffering its worst economic situation since the Great Depression at the same time that it is losing its structure with a single hegemon that has always been best for its stability - whether in the short-run this demobilization of the working class will be reversed or continued.

Then, we agree with Duménil and Lévy $(2002,2005)$ who highlight that neoliberalism has been more a political project of the ruling classes than a superior way of allocating resources under a spontaneous order of free markets. Three facts support our assertion:

1. The main characteristic of capitalism since $1973 / 74$ has been stagnation (Magdoff and Sweezy 1987; Felix 2003).

2. The state's participation in political and economic terms did not diminish in society; instead, it increased. We agree with other scholars (Polanyi 2001; Krippner 2011) who have pointed out that even free markets need the participation of the state. What has happened is that the state now does not have any commitment to social justice, and during neoliberalism, the living conditions of the workers have worsened.

3. Inequality has increased all over the world, with the upper classes, the sector that has benefited the most.

Then, for the whole society in underdeveloped countries, the goal of accelerating growth and social development is the same as before WWII. However, two important mechanisms that operated during the Keynesian period no longer exist: (1) the state-owned enterprises (SOEs) and (2) capital controls because of the encouragement of free mobility of capitals, which in turn is due to general technical (above all communications), financial, and legal changes in international capital (Campbell and Bakir 2012). Thus, with these two facts, the activities of development banks, especially in underdeveloped countries, were curtailed, notwithstanding that several development banks have been founded after 1989 (De Luna-Martínez and Vicente 2012), and some development banks currently in 
operation in developed countries have managed huge amounts of money capital (Lazzarini et al. 2002).

Development flourished after WWII. In part, development banks created the national elites of Brazil and Mexico. In this process, workers also benefited because the economy was in expansion. However, as we have mentioned, wealthy people in Latin America are much more powerful now than during the time of the ISI, and they do not need the participation of development banks to direct their businesses.

\section{Conclusion}

In order to extract lessons for a new financial architecture that would supplant the IMF and the World Bank as a source of borrowed capital in Latin American countries, we studied the following: (1) relevant issues concerning development banks today and (2) the efforts of financing development in two Latin American countries, Mexico and Brazil, through their development banks, NAFINSA and BNDES, respectively. We reached the following conclusions:

1. Differences in success between two phases of capitalism (the $|S|$ and the neoliberalism). During the ISI, there was high and sustained growth, and in addition the conditions of life for many people improved in both Mexico and Brazil. However, the ISI was not sustainable because it needed the inflow of capital via foreign debt. This fact, along with the global imposition of Neoliberalism, led to less participation of the state in directing national policies of development. The implementation of neoliberalism has had pernicious effects on people, as can be seen by the increase in poverty and inequality. Financing severely plummeted during these years because of three reasons: development banks' resources decreased compared to those during the ISI, lending was short-term instead of long-term, and development banks were second-tier financial institutions. Thus, the establishment of national policies of development was almost abandoned.

2. Differences in economic histories between Mexico and Brazil are reflected in differences in the growth pattern of both countries. Among the differences between Mexico and Brazil, we can highlight the bigger rate of inflation in Brazil than in Mexico, and the tardiness of the consolidation of government institutions to deal with money. Both of these facts, in turn, were due to the inner composition of the class struggle of each country. In Mexico, the turmoil provoked by the Revolution, and after it, the effects of the Great Depression were deeper than in Brazil. Then, a strong capitalist sector was instituted first in Mexico; meanwhile, in Brazil, industrial capitalists had to still fight with agribusiness interest, and on some occasions it was these agribusinesses who financed industrial activities. However, class conflict 
between Brazilian elites did not represent any problem since all of them clearly felt the enemy were peasants and workers and that they should not fight in a context of high growth rates.

3. The development banks affected the quality of life of the people in Latin America. To what extent did development banks successfully promote development? Existing evidence suggests that during the ISI period, there was high and sustained growth, and the quality of life for most people improved. However, we dare to say that, even during this period, development banks were good at promoting growth but not human development. Notwithstanding the capability of capitalism to create growth, the purpose of this system is to achieve a high profit in the short-run. Our argument is supported by two points of view: (a) the state promoted productive and social activities as long as it was good at keeping pace with accumulation capital, especially social expenditures were used to reproduce the labor force only (Krippner 2011); (b) the exploitation of people, the worker, and the peasant by the ruling classes is not taken into account. In fact, development banks, which are studied here, tried to promote development via conventional capitalism.

This conventional capitalism way to achieve development can be demonstrated by the destiny of the resources of development banks. Both banks included in our analysis were public in ownership, but they primarily financed the private sector. They financed public companies only because the public sector was a complement to the private or due to the market failure of the private sector. In Table 6 , we present a typology for development banks considering their ownership (public or private, rows in Table 6) and the companies they tried to foster (either public or private, columns in Table 6). European investment banks were private/private but underdeveloped countries have been public/private without catching up to the leading countries. This slow process of growth has happened because national bourgeoisies in underdeveloped countries have been subordinated to foreign companies, which is a hindrance to establishing a long-term industrial policy. As Paul Baran (1952) commented, the bourgeoisie in underdeveloped countries has not been revolutionary as it was in developed countries in the 19th century. Then, a new financial institution could be good at promoting growth on some occasions and maybe could promote development, but it had to learn from the past - otherwise a new financial institution would reproduce a new capitalism mechanism.

Table 6 Development Banks by Ownership and Type of Financing

\begin{tabular}{llll}
\hline & & & Companies \\
& & Public & Private \\
\hline \multirow{2}{*}{ Ownership } & Public & Public/public & Public/private \\
& Private & Private/public & Private/private \\
\hline
\end{tabular}




\section{Notes}

1. For Diamond, financing the public sector is more related with planning.

2. Although in some countries there are private development banks, the vast majority are public (see De Luna-Martínez and Vicente 2012).

3. Development banks are good at financing development, according to the backwardness of each country, state's intervention is accommodated (Gerschenkron 1962).

4. Nacional Financiera (NAFINSA) changed its name in 1985 to NAFIN.

5. Triner $(1996,1999)$ comments that private financing grew in the textile industry at the beginning of the 20th century.

\section{References}

Aguilar Gutiérrez, G. 1995. "La distribución del ingreso en México. Tendencias 1950-1992 y análisis por factores componentes 1984-1992." Master's thesis, UNAM.

Amsden, H. A. 2001. The Rise of the Rest: Challenges to the West from Late-Industrialized Economies. New York: Oxford University Press.

Araujo, E., L. Carpena, and A. Cunho. 2008. Brazilian Business Cycles and Growth from 1850 to 2000. Rio de Janeiro: BNDES.

Ares, M. 2007. "El estado empresario: Nacional Financiera durante la industrialización por sustitución de importaciones." Foro Internacional 2: 201-44.

Armendáriz, B. 1999. "Development Banking.” Journal of Development Economics 58 (1): 83-100.

Aubey, R. 1966. Nacional Financiera and Mexican Industry. Los Angeles: UCLA.

Baer, W., and A. Villela. 1980. "The Changing Nature of Development Banking in Brazil." Journal of Interamerican Studies and World Affairs 4: 423-40.

Baran, P. 1952. "On the Political Economy of Backwardness." The Manchester School of Economic \& Social Studies 1: 66-84.

Blair, C. 1964. "Nacional Financiera: Entrepreneurship in Mixed Economy." In Public Policy and Private Enterprise in Mexico, edited by R. Vernon, 191-240. Cambridge, MA: Harvard University Press.

BNDES (Banco Nacional de Desenvolvimento Econômico e Social). 2012. "Estatísticas operacionais." BANDES. Accessed March 10, 2012. http://www.bndes.gov.br.

Boskey, S. 1959. Problems and Practices of Development Bank. Baltimore, MD: The Johns Hopkins University Press.

Bruck, N. 1998. "The Role of Development Banks in the Twenty-First Century." International Journal of Emerging Markets 3: 39-67.

Cameron, R. 1961. France and the Economic Development of Europe 1800-1914: Conquests of Peace and Seeds of War. Princeton, NJ: Princeton University Press.

Cameron, R., ed. 1972a. Banking and Economic Development: Some Lessons of History. New York: Oxford University Press.

Cameron, R. 1972b. “Belgium, 1800-1875.” In Banking in the Early Stages of Industrialization, edited by R. Cameron, 129-50. New York: Oxford University Press.

Campbell, A., and E. Bakir. 2012. “The Pre-1980s Roofs of Neoliberal Financial Regulation.” Journal of Economic Issues 46: 531-40.

Cardoso, F. H. 1968. “Empresarios industriales y desarrollo nacional en Brasil.” Desarrollo Económico 29: 31-60.

Castro, L. 2009. "Financiamento do desenvolvimento: Experiêcia comparada Brasil-Coreia (1950-1980)." Revista do BNDES 32: 5-46.

Da Conceição Tavares, M. 1977. De la sustitución de importaciones al capitalismo financiero. México: FCE. 
De Luna-Martínez, J., and C. L. Vicente. 2012. Global Survey of Development Banks. Washington, DC: World Bank.

Diamond, W. 1957. Development Banking. Baltimore, MD: The Johns Hopkins University Press.

Diamond, W. 1981. Reflections on the Performance of Development Banks and the Challenges Ahead. Cairo: National Bank of Egypt.

Diniz, A. 2004. "BNDES: De agente desenvolvimentista a gestor da privatizaçao 1952-2002." Master's diss., Universidade Estadual de Campinas.

Duménil, G., and D. Lévy. 2002. The Nature and Contradictions of Neoliberalism. Paris: MODENCNRS and CEPREMAP-CNRS.

Duménil, G., and D. Lévy. 2005. Costs and Benefits of Neoliberalism: A Class Analysis. Paris: MODEN-CNRS and CEPREMAP-CNRS.

Felix, D. 2003. The Past as Future? The Contribution of Financial Globalization to the Current Crisis of Neo-Liberalism as a Development Strategy. Cambridge: PERI.

Fitzgerald, E. V. K. 1978. "The State and Capital Accumulation in Mexico." Journal of Latin American Studies 2: 263-82.

Garrido, C. 2002. "Industrialización y grandes empresas en el desarrollo estabilizador, 1958-1970." Revista Análisis Económico 35: 233-67.

Garrido, C., and J. Martínez. 2004. "El sistema financiero mexicano evolución recientey perspectiva." El Cotidiano 123: 19-29.

Gerschenkron, A. 1962. Economic Backwardness in Historical Perspective. Washington, DC: Frederick A. Praeger.

Golonbek, C., and M. A. Urturi. 2009. Banca de Desarrollo un estudio de caso:BNDES, diseño institucional and rol anticiclico 2007/2009. Buenos Aires: CEFIDAR.

Gonzaga, G., and D. Machado. 2003. "Rendimentos e preços." In Estadisticas do século, edited by IBGE, 465-505. Brasil: IBGE.

Green, R. 1998. "Deuda externa y banca transnacional en México 1970-1986." In Pasadoy presente de la deuda externa de México, edited by F. Rosenzweig, 155-73. México: Instituto Mora.

Guerrero, I., L. F. López-Calva, and M. Walton. 2009. The Inequality Trap and Its Links to Low Growth in Mexico. Washington, DC: World Bank.

Guth, F. 2006. “O BNDES nos anos 1990: uma análise keynesia." Master's diss., Universidade Federal do Rio de Janeiro.

Hermann, J. 2002. "Financial Structure and Financing Models: The Brazilian Experience over the 1964-1997 Period." Journal of Latin American Studies 1: 71-114.

Hermann, J. 2010. Papel e funcionalidade dos Banco Publicos: notas sobre la experiencia brasileira recente (1995-2009). Brasil: Associaçâo Keynesiana Brasileira.

Itoh, M., and C. Lapavitsas. 1999. Political Economy of Money and Finance. New York: Macmillan.

Kane, J. 1975. Development Banking: An Economic Appraisal. Lexington, MA: Lexington Books.

Krippner, G. 2011. Capitalizing on Crisis: The Political Origins of the Rise to Finance. Cambridge: Harvard University Press.

Lazzarini, S. G., A. Musacchio, R. Bandeira-de-Mello, and R. Marcon. 2002. What Development Banks Do? Evidence from Brazil, 2002-2009. Boston, MA: Harvard Business School. http://hbswk. hbs.edu/item/6915.html.

López, P. 2009. Los bancos de desarrollo en América Latina: la experiencia de Nacional Financiera durante la industrialización por substitución de importaciones mexicana (1940-1970). Madrid: Asociación Española de Historia Económica.

Magdoff, H., and P. Sweezy. 1987. Stagnation and the Financial Explosion. New York: Monthly Review Press.

Maung, M. 1973. Two Models of Foreign Development Banks. Cambridge, MA: Center for Community $\&$ Economic Development.

Polanyi, K. 2001. The Great Transformation: The Political and Economic Origins of Our Time. Boston, MA: Beacon Press. 
Ramírez, M. D. 1986. Development Banking in Mexico: The Case of the Nacional Financiera, S. A. Westport, CT: Praeger.

Sochaczewski, C. 2003. "Finanças públicas brasileiras no século XX." In Estadisticas do século, edited by IBGE, 357-80. Brasil: IBGE.

Stallings, B., and R. Studart. 2006. Finance for Development: Latin America in Comparative Perspective. Washington, DC: Brookings Institution Press.

Studart, R. 1995. Investment Finance in Economic Development. New York: Routledge.

Triner, G. 1996. "The Formation of Modern Brazilian Banking, 1906-1930: Opportunities and Constraints." Journal of Latin American Studies 1: 49-74.

Triner, G. 1999. "Banks, Regions and Nation in Brazil, 1889-1930." Latin American Perspectives 1: 129-50.

UN (United Nations). 2005. Rethinking the Role of National Development Banks: Back-Ground Document. New York: UN.

Valle, A., and G. Martínez. 2011. México, otro capitalismo fallido. Buenos Aires: Razón y Revolución.

Villa, M. R. O. 1976. Nacional Financiera: banca de fomento del desarrollo económico de México. México: NAFINSA. 